\title{
Variasi Tekanan Kerja Suction Compressor Terhadap Kinerja Ac Split dengan R290
}

\author{
Mustaqim ${ }^{1}$, Ahmad Farid, Hadi Wibowo \\ Universitas Pancasakti Tegal, Jl. Halmahera km.1 Tegal \\ http://upstegal.ac.id/
}

\begin{abstract}
Abstrak - Telah dilakukan studi eksperimen kinerja R290 pada AC split basis R22. Karena dampak negative terhadap lingkungan oleh klorin dari penggunaan R22 yang menyebabkan terjadinya penipisan lapisan ozon maka kesepakatan montreal 1997 memutuskan untuk menghapus penggunaan R22. Zat alami R290 yang memiliki ODP nol dan GWP yang dapat diabaikan dipandang memiliki potensi yang besar sebagai alternative pengganti R22. Metode penelitian ini adalah menguji R290 pada AC split 1 PK basis R22 dengan memberikan variasi tekanan kerja pada suction kompresor berturutturut sebesar 60 psi, 70 psi dan 80 psi. Pada masing-masing tekanan kerja suction kompresor yang diberikan diamati pengaruhnya terhadap kapasita pendinginan, kerja kompresor dan COP. Selanjutnya dengan metode yang sama diuji juga R22. Akhirnya kinerja R290 dan R22 dibandingkan. Hasil penelitian menunjukan bahwa kapasitas pendinginan R290 dan R22 meningkat terhadap peningkatan tekanan kerja suction yang diberikan. Semakin tinggi tekanan kerja suction, memberikan beda kapasitas pendinginan antara R290 dan R22 yang semakin besar. Perbedaan kapasitas pendinginan antara $R 22$ dan $R 290$ rata-rata mencapai 13,4\%. Sementara itu, kinerja COP R290 mencapai 15,2\% lebih rendah disbandingkan dengan $R 22$.
\end{abstract}

Kata kunci: Refrigerant Hydrocarbon, R290, COP

\section{Pendahuluan}

Refrigerant R22 telah digunakan secara luas pada sistem Pemanas, Ventilasi dan pengkondisian udara (HVAC). Khususnya pada Negara-negara berkembang yang nilai penjualan STHAC luar biasa seperti China, India, Brasil. STHAC telah menjadi alat rumah tangga yang penting dan refrigerant R22 telah mendominasi dalam penggunaannya sebagai bahan pendingin karena memiliki sifat themodinamika yang bagus dan factor keamanan yang baik pula seperti sifatnya yang non-toxid, non-flammable dan non-explosive. Namun demikian R22 masih mengandung clorine dan menyebabkan masalah lingkungan yaitu merusak ozon meskipun memiliki nilai ODP yang rendah [1]. Karena dampak negative yang ditimbulkan terhadap lingkungan dari penggunaan R22 yaitu menyebabkan terjadinya penipisan lapisan ozon (ozon depletion) dan pemanasan global (global warming), maka telah dilakukan serangkaian pertemuan montreal yang memutuskan untuk menghapus penggunaan R22. Dan selanjutnya telah ada perencanaan percepatan penghapusan HCFC yang disetujui oleh para pihak yang hadir dalam kesepakatan montreal paling lambat sampai tahun 2030 [2]. Oleh karena itu, sangat mendesak untuk mencari pengganti R22 yang tepat.

Sebagai zat alami R290 memiliki ODP nol dan GWP yang dapat diabaikan sehingga tidak membahayakan lingkungan. Bahkan R290 memiliki sifat thermodinamika dan sifat transport yang baik [3]. Berbagai eksperimen menunjukan bahwa R290 memberikan kinerja yang setara bahkan lebih baik dibanding R22 bila diberikan desain yang tepat. Selain itu R290 memiliki kompatibel dengan bahan pelumas dan material yang biasa digunakan pada HVAC [4].

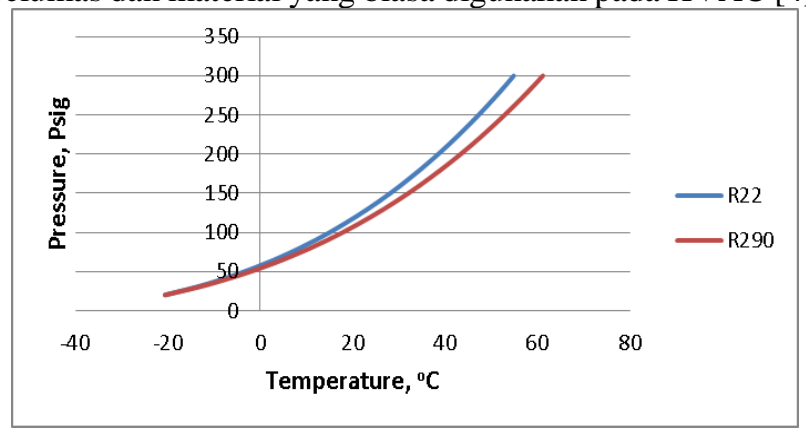

Gambar 1 Grafik hubungan antara temperatur jenuh dan tekanan jenuh R22 dan R290 (Propana). Dibuat dengan software REFPROP.

Satu-satunya masalah yang dimiliki R290 adalah sifatnya yang mudah terbakar yang dapat menimbulkan kejadian berbahaya jika tidak ditangani dengan baik [5]. Kesadaran terhadap lingkungan di masyarakat mengungkapkan bahwa R290 dipandang masyarakat sebagai refrigerant yang potensial menggantikan R22. Dalam hal ini telah dilakukan studi variasi tekanan suction kompresor terhadap kinerja R290 dan dibandingkan dengan R22. 


\section{Dasar Teori}

Mekanisme siklus pendingin kompresi uap konvensional (CVCC) ditunjukan oleh gambar 2a. Proses dari state 1 ke state 2 adalah proses kompresi melalui kompresor, dari state 2 ke state 3 adalah proses kondensasi melalui kondensor, dari state 3 ke state 4 adalah proses ekspansi melalui katup ekspansi, dari state 4 kembali ke state 1 adalah proses evaporasi memalui evaporator.

Dampak Refrigerasi adalah jumlah kalor yang diserap oleh evaporator per-satuan massa pada saat terjadi penguapan. Besarnya dihitung menggunakan persamaan :

$$
q_{r}=h_{1}-h_{4} \quad(1)
$$

dimana, $\mathrm{h}_{1}$ adalah entalpi pada awal proses kompresi $(\mathrm{kJ} / \mathrm{kg})$ dan $\mathrm{h}_{4}$ adalah entalpi pada awal proses penguapan $(\mathrm{kJ} / \mathrm{kg})$.

Kerja spesifik adalah kerja yang setara dengan perubahan entalphi selama proses kompresi dan dirumuskan sebagai berikut :

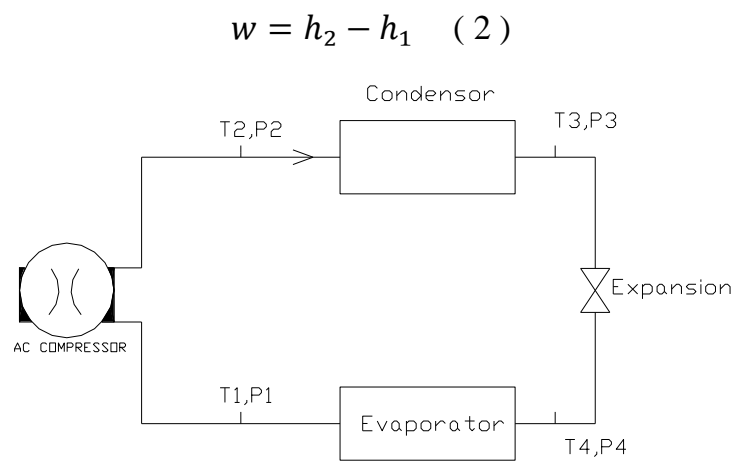

(a)

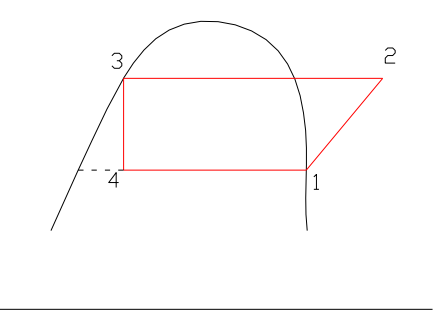

(b)

Gambar 2 (a) Siklus Pendingin kompresi uap, (b) diagram P-H siklus pendingin kompresi uap.

Dimana, w adalah kerja spesifik kompresor $(\mathrm{kJ} / \mathrm{kg}), \mathrm{h}_{2}$ adalah entalpi pada akhir proses kompresi $(\mathrm{kJ} / \mathrm{kg})$. Dengan demikian kebutuhan daya total kompresor adalah

$$
\begin{gathered}
\mathrm{W}=\dot{m}\left(h_{2}-h_{1}\right)=\dot{m}\left(\frac{\mathrm{h}_{2 \mathrm{~s}}-\mathrm{h}_{1}}{\eta_{i s}}\right)(3) \\
\eta_{\text {is }}=0,8734-0,013 \cdot \frac{P_{2}}{P_{1}}(4)
\end{gathered}
$$

Dimana, $\dot{m}$ adalah laju aliran massa refrigerant (kg.s). $\mathrm{P}_{2}$ dan $\mathrm{P}_{1}$ adalah discharge dan suction kompresor, $\eta_{\text {is }}$ adalah efisiensi isentropis [6].

Kinerja siklus mesin pendingin (AC) diukur dengan nilai COP yaitu merupakan perbandingan antara dampak refrigerasi dengan kerja spesifik kompresor,

$$
C O P=\frac{h_{1}-h_{4}}{h_{2}-h_{1}} \quad(5)
$$

\section{Metodologi Penelitian}

Perangkat uji yang digunakan pada penelitian ini adalah AC ruang R22 standart SHARP AC AH9UCY diadobsi sebagai baseline. Perangkat uji tersebut digunakan untuk menguji kinerja R290 dan sebagai pembanding digunakan R22. Kondensor

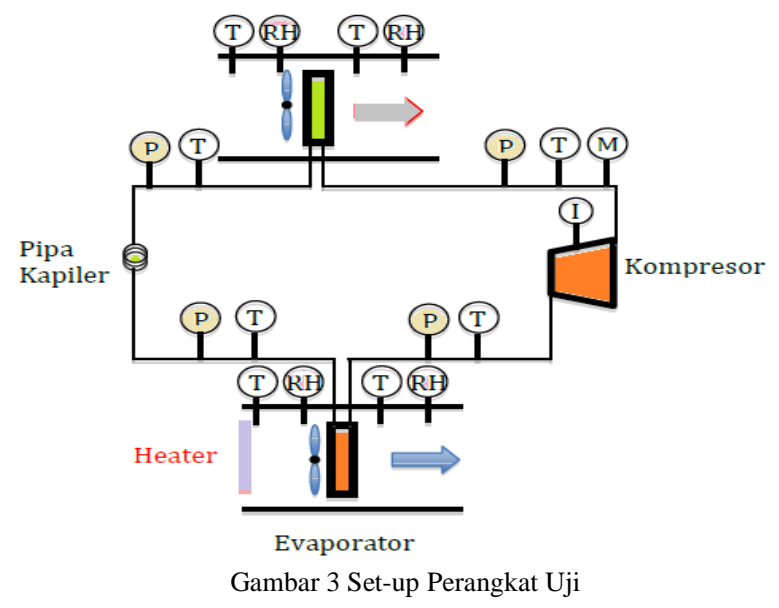

Pengujian R290 dan R22 pada perangkat eksperimen masing-masing dilakukan pada tekanan suction 60 psig, 70 psig dan 80 psig. Setiap variasi tekanan diambil data tiga kali pengujian. Pada setiap titik masuk dan keluar komponen diambil data ukur temperatur dan tekanan untuk mengetahui tingkat keadaan refrigerant pada masing-masing titik tersebut. Laju aliran massa refrigeran dihitung menggunakan persamaan daya kompresor. Dengan melakukan pengukuran arus dan tegangan listrik yang dibutuhkan oleh kompresor. Dari tiga pengambilan data pengujian pada setiap variasi tekanan suction dihitung/ diambil rata-rata, selanjutnya dengan nilai rata-rata ini kinerja R290 dan R22 ditentukan dan dianalisa.

\section{Temuan Dan Pembahasan}

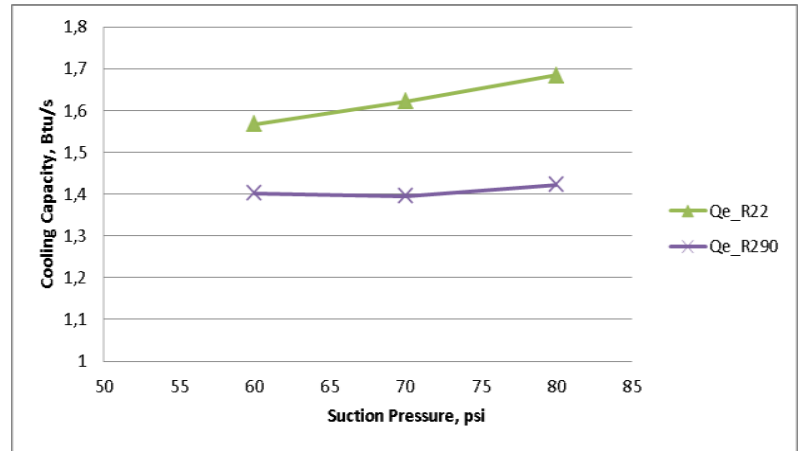

Gambar 4 Kapasitas Pendinginan Pada Berbagai Tekanan Suction Kompresor 


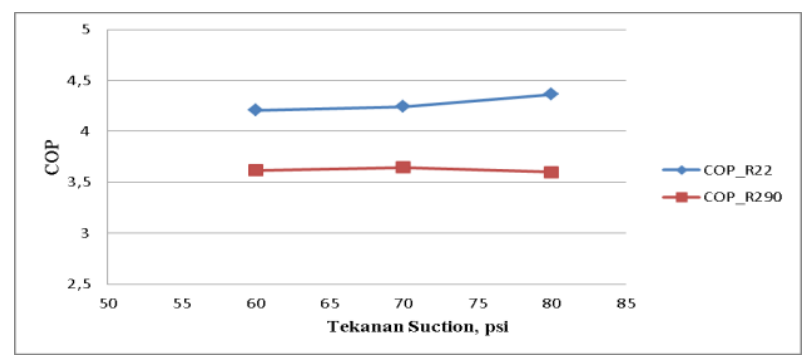

Gambar 5 COP Pada Berbagai Tekanan Suction Kompresor

Dari gambar 4 dapat dilihat bahwa baik kapasitas pendinginan R22 dan R290 pada AC split meningkat dengan bertambahnya tekanan kerja suction. Hal ini bisa terjadi karena dengan bertambahnya tekanan kerja suction juga berarti menambah massa/ refrigerant charge. Dapat dilihat pula bahwa semakin tinggi tekanan kerja suction diberikan selisih kapasitas pendinginan antara R22 dan R290 semakin besar. Perbedaan perbedaan kapasitas pendinginan antara R22 dan R290 rata-rata mencapai 13,4\%. Sementara itu gambar 5 menunjukan diagram hubungan antara berbagai tekanan kerja suction yang diberikan dengan kinerja COP untuk R22 dan R290. Dari gambar 5 dapat dilihat bahwa kinerja COP R290 pada AC split lebih rendah dari kinerja COP R22. Selisih COP antara R290 dan R22 rata-rata mencapai $15,2 \%$

\section{Simpulan}

Dari analisis hasil penelitian ini menunjukan bahwa pada tekanan rendah karakteristik thermodinamik R290 mendekati sama dengan karakteristik R22. Kapasitas panas oleh R290 pada kondensor meningkat terhadap peningkatan tekanan kerja suction kompresor yang diberikan. Kapasitas panas kondensor oleh R290 rata-rata mencapai 10,4\% lebih rendah dibanding R22. Kapasitas pendinginan oleh R290 pada evaporator meningkat terhadap peningkatan tekanan kerja suction kompresor yang diberikan. Kapasitas pendinginan oleh R290 rata-rata mencapai $13,4 \%$ lebih rendah dibanding R22. Sementara itu, COP R290 mencapai $15,2 \%$ lebih rendah dibandingkan R22. Dengan demikian secara umum R290 dapat digunakan menjadi pengganti altenatif R22 secara langsung.

\section{Kepustakaan}

[1] T. Teng, H. Mo, H. Lin, Y. Tseng, R. Liu, and Y. Long, "Retro fi t assessment of window air conditioner," vol. 32, pp. 100-107, 2012.

[2] O. Secretariat, U. Nations, and E. Programme, Handbook for the International Treaties for the Protection of the Ozone Layer, no. 1985. 2003

[3] B. J. M. Calm, F. Ashrae, and P. A. Domanski, "forum R22 REPLACEMENT STATUS," vol. 3, no. November, pp. 18-24, 2004.

[4] E. Granryd, "Hydrocarbons as refrigerants Đ an overview Á nes : vue d' ensemble Les hydrocarbures comme frigorige," vol. 24, 2001.

[5] J. H. Wu, L. D. Yang, and J. Hou, "Experimental performance study of a small wall room air conditioner retrofitted with R290 and R1270 ' rimentale sur un petit conditionneur d' air Etude expe individuel converti au R290 et au R1270," vol. 5, pp. 2-10, 2012.

[6] M. Elakdhar, E. Nehdi, and L. Kairouani, "Analysis of a Compression / Ejection Cycle for Domestic Refrigeration," pp. 4639-4644, 2007. 